\title{
PENGEMBANGAN APLIKASI WEB PENGUKURAN KINERJA UMKM MENGGUNAKAN METODE TERINTEGRASI AHP, WPM DAN BALANCED SCORECARD
}

\author{
Yulian Findawati, Atikha Sidhi Cahyana, Ika Ratna Indra Astutik \\ Teknik Informatika, Fakultas Teknik, Universitas Muhammadiyah Sidoarjo \\ Jl. Raya Gelam 250 Candi Sidoarjo Telp. 0318051771. teknik@umsida.ac.id \\ E-mail: yfindawati250783@gmail.com
}

\begin{abstract}
Performance measurement system is one of the existing models to monitor the successful implementation of the strategy objectives that have been established leadership of the company, and no exception for SME (Micro, Small and Medium Enterprises). During this time, the measurement of the performance of SMEs tend to be more focused on the financial side alone. Industry performance measurement of the financial aspect is important, but there is still aspect that also important and need to be considered because the effect on the performance aspects of industrial SMEs are customers, internal business processes and learning and growth. It is necessary for the performance of SME development model based performance measurement system that is appropriate to the nature and characteristics of SMEs. In this case, the Balanced Scorecard is a performance measurement method that is deemed suitable for SMEs in Indonesia. Therefore, researchers apply the balanced scorecard performance measurement models to the application program in the form of web-based SME performance measurement using the programming language PHP and MySQL that measures the performance of SMEs can be run effectively and efficiently. The test is done by doing research on SMEs located in Sidoarjo. Sample data is existing SMEs in Sidoarjo. For performance measurement criteria based on the Balanced Scorecard method, namely financial perspective, customer perspective, internal process perspective and the perspective of development. While the method of AHP (Analytic Hierarchy Process) is used for the weighing of the criteria, sub-criteria and the final assessment, while the choice of sub-criteria weighted indicators using the Weighted Product Model (WPM). Weighting of the criteria and sub-criteria prioritization is done based on the interest rate. The results of the analysis and design of the system will be applied to the application of Web-based SME performance measurement. The output of this application is the value of SME performance improvement solutions with recommendations to SMEs.
\end{abstract}

\section{Abstrak}

Sistem pengukuran kinerja merupakan salah satu model yang ada untuk memonitor keberhasilan implementasi strategi objektif yang telah ditetapkan pimpinan perusahaan, tidak terkecuali UMKM (Usaha Mikro, Kecil dan Menengah). Selama ini, pengukuran kinerja UMKM cenderung lebih memfokuskan terhadap sisi keuangan saja. Pengukuran kinerja industri dari aspek keuangan memang penting, tetapi masih ada aspek lain yang juga penting dan perlu diperhatikan karena berpengaruh terhadap kinerja industri UMKM yaitu aspek pelanggan, proses bisnis internal dan proses pembelajaran dan pertumbuhan. Untuk itu perlu model pengembangan kinerja UMKM berdasarkan sistem pengukuran kinerja yang sesuai dengan sifat dan karakteristik UMKM. Dalam hal ini, Balanced Scorecard adalah metode pengukuran kinerja yang dipandang cocok untuk UMKM di Indonesia. Oleh karena itu peneliti mencoba mengaplikasikan model pengukuran kinerja Balanced scorecard ke dalam bentuk program aplikasi pengukuran kinerja UMKM berbasis web menggunakan bahasa pemrograman PHP dan MySQL sehingga pengukuran kinerja UMKM dapat berjalan efektif dan efisien. Uji coba dilakukan dengan melakukan penelitian di UMKM yang berada di Kabupaten Sidoarjo. Sample Data adalah UMKM yang ada di Sidoarjo. Untuk kriteria pengukuran kinerja berdasarkan metode Balanced Scorecard yaitu perspektif financial, perspektif pelanggan, Perspektif proses internal dan perspektif pengembangan. Sedangkan metode AHP (Analytic Hierarchy Process) digunakan untuk pembobotan kriteria, subkriteria serta penilaian akhir, sedangkan pembobotan indikator pilihan dari subkriteria menggunakan metode Weighted Product Model (WPM). Pembobotan kriteria dan subkriteria dilakukan berdasarkan penentuan prioritas tingkat kepentingan. Hasil dari analisa dan perancangan sistem akan diaplikasikan ke dalam aplikasi pengukuran kinerja UMKM berbasis Web. Output dari aplikasi ini adalah nilai kinerja UMKM beserta rekomendasi solusi perbaikan terhadap UMKM.

Kata kunci: AHP, WPM, balanced scorecard 
Findawati, dkk., Pengembangan Aplikasi Web Pengukuran Kinerja UMKM menggunakan Metode..

\section{PENDAHULUAN}

Perkembangan UMKM (Usaha mikro, kecil dan menengah) di Indonesia sangatlah pesat dari tahun ke tahun (Sriyana, Jaka. 2010). Sektor usaha mikro, kecil dan menengah merupakan bagian integral dari perekonomian nasional yang mempunyai kedudukan, potensi dan peranan yang penting dan strategis dalam mewujudkan pembangunan ekonomi nasional yang kokoh. Berdasarkan data Kementerian Koperasi \& UMKM, jumlah UMKM (Usaha Mikro, Kecil dan Menengah) di Indonesia pada tahun 2011 meningkat 2, $57 \%$ daripada tahun sebelumnya, dimana jumlah populasi UMKM pada tahun 2011 mencapai 55, 21 juta usaha atau 99.99 persen dari total unit usaha di Indonesia, dengan penyerapan tenaga kerja sebanyak 94 juta pekerja pada usaha mikro dan 3, 9 juta pekerja pada usaha kecil serta 2, 8 juta pada usaha menengah. Namun UMKM memiliki permasalahan sehingga sulit berkembang. Adapun permasalahan UMKM menurut Marbun, 1993 yaitu Tidak atau jarang adanya perencanaan yang tertulis, tidak berorientasi ke depan, tidak memiliki pendidikan yang relevan, tidak ada pembukuan yang teratur, tidak mengadakan analisis pasar yang up to date, kurang spesialisasi atau diversifikasi berencana, jarang terjadi pengkaderan, kurang percaya pada ilmu modern, dan keluarga sentris. Dengan kondisi UMKM yang hanya berkembang dari segi kuantitas namun dari segi kualitas belum berkembang, menyebabkan daya saing yang dimiliki UMKM masih sangat rendah. Oleh karena itu diperlukan model pengukuran kinerja sehingga UMKM dapat mengetahui posisi dirinya di dunia industri dan dapat memperbaiki kinerjanya.

Sistem pengukuran kinerja merupakan salah satu model yang ada untuk memonitor keberhasilan implementasi strategi objektif yang telah ditetapkan pimpinan perusahaan, tidak terkecuali UMKM. Evaluasi kinerja sangat penting didalam mengukur prestasi kerja suatu perusahaan (A.Yudhi, 2008). Hasil pengukuran tersebut kemudian digunakan sebagai umpan balik yang akan memberikan informasi tentang prestasi pelaksanaan suatu rencana dan titik dimana perusahaan memerlukan penyesuaian atas aktivitas perencanaan dan pengendalian (Yuwono, 2002). Implementasi sistem pengukuran kinerja dalam konteks perusahaan di Indonesia telah banyak dilakukan. Sementara itu, metode pengukuran kinerja (performance measurement) telah berkembang pesat. Para akademisi dan praktisi telah banyak mengimplementasikan model-model baru dari sistem pengukuran kinerja perusahaan, antara lain Balanced Score- card, Integrated Performance Measurement System dan SMART System.

Berdasarkan kondisi itulah, perlu dilakukan upaya penelaahan terhadap strategi bisnis UMKM dalam kerangka pengembangan kinerja UMKM yang berfokus peningkatan daya saing dimasa datang. Untuk itu perlu model pengembangan kinerja UMKM berdasarkan sistem pengukuran kinerja yang sesuai dengan sifat dan karakteristik UMKM. Dalam hal ini, Balanced Scorecard adalah metode pengukuran kinerja yang dipandang cocok untuk UMKM di Indonesia. Balanced Scorecard (Kaplan dan Norton, 1996) merupakan kerangka manajemen yang yang menerjemahkan visi dan misi perusahaan ke dalam satu set pengukuran kinerja berdasarkan empat perspektif, yaitu perspektif keuangan, perspektif pelanggan, perspektif proses bisnis internal, serta perspektif pembelajaran dan pertumbuhan.

Oleh karena itu peneliti mencoba membuat mengaplikasikan model pengukuran kinerja ke dalam bentuk program aplikasi pengukuran kinerja UMKM berbasis web menggunakan bahasa pemrograman PHP dan MYSQL, dimana pihak UMKM dapat melakukan pengukuran terhadap dirinya sendiri (Self Assesment) dan pihak asesor eksternal dapat melakukan pengukuran terhadap UMKM (Enviromental Assesment) sehingga pengukuran kinerja UMKM dapat berjalan efektif dan efisien. Uji coba dilakukan dengan melakukan penelitian di UMKM yang berada di Kabupaten Sidoarjo. Untuk kriteria pengukuran kinerja berdasarkan metode Balanced Scorecard yaitu perspektif financial, perspektif pelanggan, Perspektif proses internal dan perspektif pengembangan. Sedangkan pembobotan kriteria, subkriteria serta penilaian akhir menggunakan metode AHP (Analytic Hirarchy Process) sedangkan metode Weighted Product Model (WPM) yang digunakan untuk menentukan pembobotan pada level indikator pilihan pada subkriteria. Metode Analytic Hierarchy Process (AHP) dikembangkan oleh Prof. Thomas Lorie Saaty dari Wharston Business school untuk mencari ranking atau urutan prioritas dari berbagai alternatif dalam pemecahan suatu permasalahan yang menghasilkan Pembobotan kriteria dan subkriteria dilakukan berdasarkan tingkat kepentingan. Dimana AHP sangat berguna dalam masalah kompleks yang tidak terstruktur, seperti pada pengukuran kinerja UMKM ini yang memiliki 4 kriteria dan 20 subkriteria dengan nilai pendukung pada beberapa sub-kriteria yang bersifat dinamis dan tidak terstruktur. Selain itu pembobotan menggunakan AHP sangat memperhatikan hubungan atau tingkat kepentingan suatu kriteria terhadap 
kriteria lain. Output dari aplikasi ini adalah nilai kinerja UMKM yang teridiri dari sangat baik, baik, cukup baik, buruk, dan sangat buruk beserta rekomendasi solusi perbaikan terhadap UMKM. Dengan adanya aplikasi ini diharapkan UMKM mengetahui posisi kinerjanya sehingga dapat memperbaiki dan meningkatkan kinerja bisnisnya.

Tujuan dari pengembangan web ini antara lain untuk membantu pengukuran kinerja pada UMKM khususnya UMKM di sidoarjo baik secara self assesment maupun enviromental assesment. Dimana self assesment yaitu pengukuran dilakukan oleh UMKM sendiri sehingga bisa menilai kinerjanya sendiri maupun mengetahui indikator yang dibutuhkan di dalam meningkatkan kinerjanya sedangkan environmental assessment yaitu pengukuran dilakukan oleh pihak eksternal sehingga pengukuran bisa dilakukan secara profesional. Tujuan kedua dari penelitian ini adalah melakukan analisa dan perancangan yaitu analisa metode Balanced scorecard, analisa pembobotan AHP, pembobotan WPM, perancangan aplikasi, coding dan pengujian. Tujuan akhir adalah mengimplementasikan dari analisa dan perancangan sistem dengan cara melakukan coding dari tiap-tiap modul berupa aplikasi pengukuran kinerja UMKM menggunakan metode Balanced Scorecard, AHP dan WPM.

Penelitian ini diharapkan dapat membawa manfaat bagi akademisi dan praktisi. Penelitian ini diharapkan dapat memberi sumbangan ilmiah dan keilmuan karena memberikan kontribusi bagi pengembangan pengetahuan tentang peningkatan kualitas UMKM. Selain itu, penelitian ini juga diharapkan dapat dijadikan pedoman dan wawasan bagi pihak UMKM yaitu Pihak UMKM dapat mengukur kinerja UMKMnya sendiri dan Pihak UMKM dapat meningkatkan kinerja UMKMnya berdasarkan rekomendasi yang diberikan oleh aplikasi

\section{METODOLOGI}

Dalam penelitian ini metodologi yang digunakan dimulai dari sistem pengukuran kerja UKM dan telaah metode yang dipakai yaitu Analytic Hierarchy Process (AHP). Setelah itu, penilaian kinerja dilanjutkan dengan pembuatan Balanced Scorecard dan pembobotan menggunakan Weighted Product Model (WPM).

\subsection{Sistem Pengukuran Kinerja dan Definisi UMKM}

Pengukuran kinerja adalah tindakan pengukuran yang dilakukan terhadap berbagai aktivitas dalam rantai nilai yang ada pada perusahaan. Hasil pengukuran tersebut kemudian digunakan sebagai umpan balik yang akan memberikan informasi tentang prestasi pelaksanaan suatu rencana dan titik dimana perusahaan memerlukan penyesuaian atas aktivitas perencanaan dan pengendalian (Yuwono). Tabel 1 menjelaskan mengenai definisi Usaha Mikro dan Menengah.

Kinerja perusahaan didefinisikan sebagai kemampuan perusahaan untuk membuat tindakan dan hasil yang dapat diterima (Pfeffer \& Salancik, 1978). Namun kinerja perusahaan harus dapat dikonsepkann dan diopersionalisasikan, serta dapat diukur dalam beberapa cara. Alasadi dan Abdelrahim (2007) menyatakan kinerja pada UKM dapat dilihat dari kepuasan pemilik/ manajer (variabel bergantung) atas: profit, omset, tahap balik modal (Break Even Point), dan pengembangan usaha.

\subsection{Analytic Hierachy Process}

Metode Analytic Hierarchy Process (AHP) dikembangkan oleh Prof. Thomas Lorie Saaty dari Wharston Business school untuk mencari ranking atau urutan prioritas dari berbagai alternatif dalam pemecahan suatu permasalahan. Dalam kehidupan sehari-hari, seseorang senantiasa dihadapkan untuk melakukan pilihan dari berbagai alternatif. Disini diperlukan penentuan prioritas dan uji konsistensi terhadap pilihan pilihan yang telah dilakukan. Dalam situasi yang kompleks, pengambilan keputusan tidak dipengaruhi oleh satu faktor saja melainkan multifaktor dan mencakup berbagai jenjang maupun kepentingan.

Tabel 1 Definisi Usaha Mikro dan Menengah

\begin{tabular}{|c|c|c|}
\hline Organisasi & Jenis Usaha & Kriteria \\
\hline \multirow[t]{6}{*}{$\begin{array}{l}\text { Bank } \\
\text { Indonesia } \\
\text { (BI) }\end{array}$} & \multirow[t]{3}{*}{$\begin{array}{l}\text { Usaha Mikro } \\
\text { (SK Dir BI No } \\
\text { 31/24/KEP/ } \\
\text { DIR Tgl } 5 \text { Mei } \\
\text { 1998) }\end{array}$} & $\begin{array}{l}\text { Usaha yang } \\
\text { dijalankan oleh } \\
\text { rakyat miskin atau } \\
\text { mendekati miskin }\end{array}$ \\
\hline & & $\begin{array}{l}\text { Dimiliki oleh } \\
\text { keluarga sumber } \\
\text { daya lokal dan } \\
\text { teknologi } \\
\text { sederhana }\end{array}$ \\
\hline & & $\begin{array}{l}\text { Lapangan usaha } \\
\text { mudah untuk exit } \\
\text { dan entry }\end{array}$ \\
\hline & \multirow{3}{*}{$\begin{array}{l}\text { Usaha } \\
\text { Menengah } \\
\text { (SK Dir BI No } \\
\text { 30/45/Dir/ UK } \\
\text { tgl 5 Januari } \\
\text { 1997) }\end{array}$} & $\begin{array}{l}\text { Aset }<\text { Rp } 5 \mathrm{M} \\
\text { untuk industri }\end{array}$ \\
\hline & & $\begin{array}{l}\text { Aset }<\text { Rp } 600 \text { juta } \\
\text { diluar tanah } \& \\
\text { bangunan }\end{array}$ \\
\hline & & $\begin{array}{l}\text { Omzet tahunan < } \\
\operatorname{Rp} 3 \mathrm{M}\end{array}$ \\
\hline
\end{tabular}


Findawati, dkk., Pengembangan Aplikasi Web Pengukuran Kinerja UMKM menggunakan Metode..

Tahapan-tahapan pengambilan keputusan dalam metode AHP ( Saaty, Thomas L. 2008) pada dasarnya meliputi:

1. Mendefinisikan masalah dan menentukan solusi yang diinginkan

2. Membuat struktur hirarki yang diawali dengan tujuan umum, dilanjutkan dengan kriteria, sub kriteria dan alternatif pilihan yang ingin di ranking

3. Membentuk matriks perbandingan berpasangan yang menggambarkan kontribusi relatif atau pengaruh setiap elemen terhadap setiap tujuan atau kriteria yang setingkat diatasnya. Perbandingan dilakukan berdasarkan pilihan atau "judgment" dari pembuat keputusan dengan menilai tingkat kepentingan suatu elemen dibandingkan elemen lainnya, ditunjukkan pada Tabel 2.

4. Menormalkan data yaitu dengan membagi nilai dari setiap elemen di dalam matriks yang berpasangan dengan nilai total dari setiap kolom

5. Menghitung nilai eigen vector dan menguji konsistensinya, jika tidak konsisten pengambil data (preferensi) perlu diulangi. Nilai eigen vector yang dimaksud adalah nilai eigen vector maximum yang diperoleh dengan menggunakan matlab maupun manual

6. Mengulangi langkah 3,4 , dan 5 untuk seluruh tingkat hirarki

7. Menghitung eigen vector dari setiap matrik perbandingan berpasangan. Nilai eigen vector merupakan bobot setiap elemen. Langkah ini mensintesis pilihan dan penentuan prioritas elemen elemen pada tingkat hirarki terendah sampai pencapaian tujuan Menguji konsistensi hirarki. Jika tidak memenuhi dengan $\mathrm{CR}<0,100$ maka penilaian harus diulang kembali.

Tabel 2. Tabel Tingkat Kepentingan

\begin{tabular}{cl}
\hline $\begin{array}{c}\text { Tingkat } \\
\text { Kepentingan }\end{array}$ & \multicolumn{1}{c}{ Definisi } \\
\hline 1 & $\begin{array}{l}\text { Sama pentingnya dibanding } \\
\text { yang lain }\end{array}$ \\
\hline 3 & $\begin{array}{l}\text { Moderat (Cukup) pentingnya } \\
\text { dibanding yang lain }\end{array}$ \\
\hline 5 & $\begin{array}{l}\text { Kuat pentingnya dibanding } \\
\text { yang lain }\end{array}$ \\
\hline 7 & $\begin{array}{l}\text { Sangat kuat pentingnya } \\
\text { dibanding yang lain }\end{array}$ \\
\hline 9 & $\begin{array}{l}\text { Ekstrim pentingnya } \\
\text { dibanding yang lain }\end{array}$ \\
\hline $2,4,6,8$ & $\begin{array}{l}\text { Nilai diantara dua nilai yang } \\
\text { berdekatan }\end{array}$ \\
\hline
\end{tabular}

\subsection{Balanced Scorecard}

Balanced Scorecard merupakan kerangka manajemen yang yang menerjemahkan visi dan misi perusahaan ke dalam satu set pengukuran kinerja berdasarkan empat perspektif, yaitu perspektif keuangan, perspektif pelanggan, perspektif proses bisnis internal, serta perspektif pembelajaran dan pertumbuhan (Kaplan dan Norton, 2001

\subsection{Metode Weighted Product Model (WPM)}

Weighted Product Model (WPM) menggunakan perkalian untuk meranking alternatif (Triantaphyllou, 2002). Tiap alternatif dibandingkan dengan yang lainnya dengan mengkalikan bilangan ratio, satu untuk tiap kriteria. Tiap rasio dinaikkan untuk kekuatan dari bobot relative dari kriteria yang cocok. Umumnya, di dalam membandingkan 2 alternatif, rumus yang digunakan adalah sebagai berikut

$$
\begin{aligned}
& A_{i, W P M-s c o r e}=\prod_{j=1}^{n}\left(a_{i j}\right)^{w_{j}} \\
& \text { for } i=1,2,3, \ldots m
\end{aligned}
$$

dimana:

$\mathrm{a}_{\mathrm{ij}}=$ alternatif pilihan

$\mathrm{w}_{\mathrm{ij}}=$ bobot kriteria

\subsection{Positioning Penelitian (Critical Review)}

Dibandingkan dengan penelitian yang telah dilakukan sebelumnya, penelitian ini memberikan tidak hanya melakukan pengukuran kinerja tetapi juga mengaplikasikan model pengukuran kinerja ke dalam suatu produk aplikasi program dimana aplikasi tersebut UMKM dapat menginputkan data UMKM dan melakukan pengukuran kinerja UMKMnya sendiri dan setelah dilakukan pengukuran kinerja, aplikasi tersebut akan memberikan rekomendasi usulan perbaikan UMKM. Berikut ini adalah tabel 3 yang berisi tabulasi tentang penelitian sebelumnya yang akan dilakukan positioning/perbandingan terhadap penelitian ini. Adapun metodologi penelitian dapat dilihat pada gambar sebagai berikut. Adapun tahapan yang dilakukan dalam penelitian yaitu pengumpulan data, analisa dan perancangan serta pengujian.

\subsection{Tahap pengumpulan data}

1. Studi Literatur

Peneliti mencari bahan-bahan pustaka yang berhubungan dengan UMKM, pengukuran kinerja pembelajaran dan pertumbuhan, metode AHP, metode WPM 
Tabel 3. Tabel Positioning Penelitian

\begin{tabular}{|c|c|c|c|}
\hline No & $\begin{array}{c}\text { Penulis dan } \\
\text { Tahun }\end{array}$ & Judul Penelitian & Hasil \\
\hline 1 & Agus Taman & $\begin{array}{l}\text { Model Pengukuran kinerja } \\
\text { perusahaan dengan metode } \\
\text { SMART System } \\
\text { http://www.gunadarma.ac.id/libra } \\
\text { ry/articles/graduate/economy/200 } \\
\text { 9/Artikel_10205056.pdf . diakses } \\
\text { 2 Januari 2013 }\end{array}$ & $\begin{array}{l}\text { Pengukuran kinerja perusahaan menggunakan } \\
\text { metode SMART System sehingga yang } \\
\text { digunakan untuk matriks pengukuran kinerja } \\
\text { yaitu } 21 \text { strategi objektif dan } 28 \text { Key } \\
\text { Performance Indicator(KPI). Belum ada aplikasi } \\
\text { web }\end{array}$ \\
\hline 2 & $\begin{array}{l}\text { Dian } \\
\text { Ramadhani }\end{array}$ & $\begin{array}{l}\text { Analisa kinerja UKM pengolahan } \\
\text { keripik pisang di Bandar } \\
\text { Lampung dengan menggunakan } \\
\text { metode Quality Function } \\
\text { Deployment } \\
\text { http://www.gunadarma.ac.id/libra } \\
\text { ry/articles/graduate/industrial- } \\
\text { technology/2006/Artikel_3040228 } \\
\text { 8.pdf diakses } 4 \text { februari } 2013\end{array}$ & $\begin{array}{l}\text { Analisa kinerja UKM menggunakan metode } \\
\text { QFD dengan hasil memberikan } 5 \text { usulan } \\
\text { alternatif perbaikan kinerja UKM pengolahan } \\
\text { kripik pisang di Bandar Lampung yaitu } 22.29 \% \\
\text { inovasi dalam kerja operasi, 20.35\% kualitas dan } \\
\text { produktivitas dalam kinerja operasi, } 14.59 \% \\
\text { organisasi dan motivasi dalam kinerja } \\
\text { manajemen sumber daya, } 12.02 \% \text { penjualan dan } \\
\text { posisi pasar dalam kinerja operasi, } 11.82 \text { publik } \\
\text { dan lingkungan dalam kinerja hubungan dengan } \\
\text { lingkungan. Belum ada aplikasi web }\end{array}$ \\
\hline 3 & Safirin, MT & $\begin{array}{l}\text { Kajian Kinerja Industri Kecil } \\
\text { dengan metode Balanced } \\
\text { Scorecard dan Analiytical } \\
\text { Hierarchy Process. Jurnal Teknik } \\
\text { Industri Universitas } \\
\text { Muhammadiyah Malang, Vol. 11, } \\
\text { Nomor 1, Februari } 2010\end{array}$ & $\begin{array}{l}\text { Hasil penelitian menunjukkan bahwa rata-rata } \\
\text { kinerja sentra industri kecil patung Batu di } \\
\text { Trowulan sebesar } 2.083 \text { (Kategori Cukup). Lebih } \\
\text { jauh lagi, ada } 2 \text { perspektif yang bobotnya sangat } \\
\text { besar terhadap kinerja industri kecil patung batu } \\
\text { yaitu keuangan dan pelanggan. Sedang faktor } \\
\text { keberhasilan terhadap rendahnya kedua } \\
\text { perspektif tersebut adalah TATO dan jumlah } \\
\text { pelanggan baru. Belum ada aplikasi web }\end{array}$ \\
\hline
\end{tabular}

2. Studi Lapangan

Melakukan studi lapangan yaitu dengan Survey tentang keberadaan UMKM di sidoarjo, yaitu dengan mengambil 50 sample data UMKM sebagai pengukuran kinerja UMKM. Data dilakukan dengan melakukan deep interview pada 50 UMKM tersebut. Sedangkan tingkat kepentingan kriteria, subkriteria dan indikator dilakukan kuisioner pada dinas UMKM di sidoarjo

\subsection{Tahap Analisa}

Analisa Kebutuhan perangkat keras

Perangkat keras yang digunakan dalam pembuatan aplikasi ini:

1. Processor Intel Pentium $4800 \mathrm{MHz}$

2. RAM 512MB

3. $H D 20 \mathrm{~GB}$

Perangkat Lunak (Software)

1. Sistem Operasi Windows Xp Profesional Edition Sistem operasi Windows digunakan karena sistem operasi ini telah mendukung GUI (Graphical User Interface) yaitu antar muka yang berbasis mode grafis dan dengan pertimbangan karena sistem operasi Windows kompatibel dengan perangkat lunak lainnya yang digunakan dalam membangun aplikasi ini.
2. Macromedia Dreamweaver MX 2004

Macromedia Dreamweaver digunakan sebagai editor untuk pembuatan halaman web, karena Dreamweaver mendukung bahasa pemrograman PHP, Java Script, dan mudah dalam pembuatan tampilan user interface.

3. Apache HTTP Server 1.5.3a sebagai web server.

4. PHP 5.1.4 sebagai Bahasa Pemrograman berbasis web.

5. MySQL Server MySQL Server digunakan sebagai database server karena MySQL sangat mendukung bahasa pemrograman PHP.

\subsection{Analisa identifikasi kriteria}

Adapun kriteria dan subkriteria yang dilakukan untuk melakukan pengukuran kinerja UMKM dengan menggunakan metode balanced scorecard (Gambar 2) yaitu:

1. Aspek keuangan
a. Return On total Assets (ROA)
b. Return On Investment (ROI)
c. Return on Equity (ROE)
d. Prosentase Profit Margin
e. Prosentase Sales Growth
f. Total Assets Turnover (TATO) 
Findawati, dkk., Pengembangan Aplikasi Web Pengukuran Kinerja UMKM menggunakan Metode..

2. Aspek pelanggan
a. Customer retention $(\mathrm{CRe})$
b. Customer Acquisition
c. Persentage Of Complain (PC)
d. On Time Delivery (OTD)
e. Sales Return (SR)

3. Aspek proses bisnis internal
a. Supplier Lead Time (SLT)
b. Percentage Of Defective Unit (PDU)
c. Number of Transaction

4. Aspek pertumbuhan dan Pembelajaran
a. Employee Turn Over (ETO)
b. Suggestion Rate (SR)
c. Absenteeism
d. Tardiness
e. Percentage Of New Employee (PNE)
f. Employee Training (ET)

a. Analisa Pembobotan Kriteria dan subriteria menggunakan AHP

Adapun perhitungan pembobotan pada kriteria yaitu menggunakan metode AHP yang dapat dijelaskan sebagai berikut :

1. Mendefinisikan masalah dan menentukan solusi yang diinginkan. Adapun permasalahannya yaitu melakukan perhitungan pengukuran kinerja UMKM. Solusi yang diinginkan yaitu hasil akhir pengukuran kinerja UMKM yang terbagi atas 5 kriteria yaitu sangat baik, baik, cukup baik, buruk dan sangat buruk.

2. Membuat struktur hirarki yang diawali dengan tujuan umum, dilanjutkan dengan kriteria perspektif balanced scorecard dan sub kriterianya. Untuk pembobotan kriteria aspek keuangan, aspek pelanggan, aspek proses bisnis internal dan aspek proses pembelajaran dan pertumbuhan $(\mathrm{P}$ dan $\mathrm{P})$ menggunakan AHP, sedangkan untuk sub kriteria meng-gunakan pembobotan WPM (Weighted Product Model).
3. Membentuk matriks perbandingan berpasangan yang menggambarkan kontribusi relatif atau pengaruh setiap elemen terhadap setiap tujuan atau kriteria yang setingkat diatasnya. Perbandingan dilakukan berdasarkan pilihan atau "judgment" dari pembuat keputusan yaitu UMKM dengan menilai tingkat kepentingan suatu elemen dibandingkan elemen lainnya.

4. Menormalkan data yaitu dengan membagi nilai dari setiap elemen di dalam matriks yang berpasangan dengan nilai total dari setiap kolom. Menghitung nilai eigen vector dan menguji konsistensinya, jika tidak konsisten pengambil data (preferensi) perlu diulangi. Nilai eigen vector yang dimaksud adalah nilai eigen vector maximum yang diperoleh dengan menggunakan matlab maupun manual

Nilai eigen keuangan $=2,387 / 0,597=4$

Nilai eigen pelanggan $=0,221 / 0,055=4$

Nilai eigen proses bisnis internal $=$ $0,917 / 0,229=4$

Nilai eigen pertumbuhan $\&$ pembelajaran $=$ $0,475 / 0,119=4$

$$
\begin{aligned}
& \text { Hasil Consistency Index }(\mathbf{C I}) \\
& \begin{aligned}
\mathrm{CI}=\left(\square_{\max }-\mathrm{n}\right) / \mathrm{n}-1 & =(4-4 / 4-1 \\
& =0 / 3 \\
& =0
\end{aligned}
\end{aligned}
$$

Jadi, 0 merupakan hasil dari consistency index

\section{Hasil Consistency Ratio (CR)}

$\mathrm{CR}=($ Hasil CI/Nilai Indeks Random kolom ke 3) $=0 / 1,12=0$

Jadi, 0 merupakan hasil dari consistency ratio Karena $\mathrm{CR}=0<0,1$, maka matriks perbandingannya konsisten.

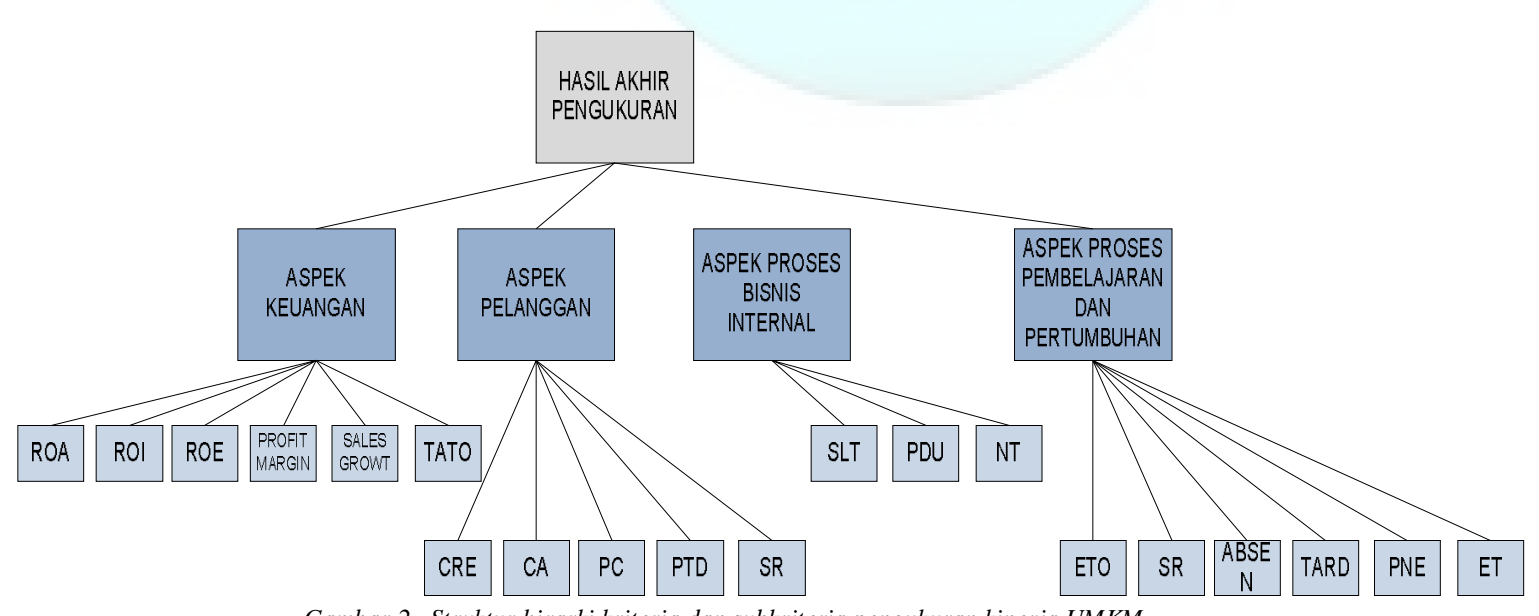

Gambar 2. Struktur hirarki kriteria dan subkriteria pengukuran kinerja UMKM 
Tabel 4. matriks perbandingan berpasangan kriteria

\begin{tabular}{lcccc}
\hline & Keuangan & Pelanggan & Proses Bisnis Internal & P dan P \\
\hline Keuangan & 1 & 7 & 5 & 5 \\
Pelanggan & 0.143 & 1 & 0.2 & 0.333 \\
Proses Bisnis Internal & 0.2 & 5 & 1 & 3 \\
P dan P & 0.2 & 3 & 0.333 & 1 \\
& 1.543 & 16 & 6.533 & 9.333 \\
\hline
\end{tabular}

Selanjutnya untuk pembobotan subkriteria pada aspek keuangan juga menggunakan metode AHP dapat dilihat pada proses berikut :

1. Membentuk matriks perbandingan berpasangan yang menggambarkan kontribusi relatif atau pengaruh setiap elemen terhadap masing-masing tujuan atau kriteria yang setingkat diatasnya. (Tabel 4)

2. Menormalkan data yaitu dengan membagi nilai dari setiap elemen di dalam matriks yang berpasangan dengan nilai total dari setiap kolom

3. Menghitung nilai eigen vector dan menguji konsistensinya, jika tidak konsisten pengambil data (preferensi) perlu diulangi. Nilai eigen vector yang dimaksud adalah nilai eigen vector maximum yang diperoleh dengan menggunakan matlab maupun manual

Nilai eigen $\mathrm{ROA}=0,3 / 0,049=6$

Nilai eigen $\mathrm{ROI}=1,396 / 0,232=6$

Nilai eigen $\mathrm{ROE}=1,963 / 0,327=6$

Nilai eigen Profit Margin $=1,005 / 0,167=6$

Nilai eigen Sales Growth $=0,608 / 0,101=6$

Nilai eigen $\mathrm{TATO}=0,728 / 0,121=6$

\section{Hasil Consistency Index (CI)}

$\mathrm{CI}=\left(\square_{\max }-\mathrm{n}\right) / \mathrm{n}-1$

$=6-6 / 5-1=0 / 4=0$

Jadi, 0 merupakan hasil dari consistency index

\section{Hasil Consistency Ratio (CR)}

$\mathrm{CR}=($ Hasil CI / Nilai Indeks Random kolom ke $3)=0 / 1,24=0$

Jadi, 0 merupakan hasil dari consistency ratio

Karena $\mathrm{CR}=0<0,1$, maka matriks perbandingannya konsisten.

Tabel 5 matriks perbandingan berpasangan aspek keuangan

\begin{tabular}{lcccccc}
\hline & ROA & ROI & ROE & pf & sg & TATO \\
\hline ROA & 1 & 0.2 & 0.143 & 3 & 0.333 & 0.2 \\
\hline ROI & 5 & 1 & 0.5 & 7 & 5 & 3 \\
\hline ROE & 7 & 2 & 1 & 7 & 5 & 5 \\
\hline pf & 0.33 & 0.143 & 3 & 1 & 0.333 & 5 \\
\hline sg & 3 & 0.2 & 0.2 & 3 & 1 & 3 \\
\hline TATO & 5 & 0.333 & 0.2 & 0.2 & 5 & 1 \\
\hline & 21.3 & 3.876 & 5.04 & 21.2 & 16.67 & 17.2 \\
\hline
\end{tabular}

Selanjutnya untuk pembobotan subkriteria pada aspek pelanggan juga menggunakan metode AHP dapat dilihat pada proses berikut :

1. Membentuk matriks perbandingan berpasangan yang menggambarkan kontribusi relatif atau pengaruh setiap elemen terhadap setiap tujuan atau kriteria yang setingkat diatasnya (Tabel 5, 6, 7, 8).

2. Menormalkan data yaitu dengan membagi nilai dari setiap elemen di dalam matriks yang berpasangan dengan nilai total dari setiap kolom

3. Menghitung nilai eigen vector dan menguji konsistensinya, jika tidak konsisten pengambil data (preferensi) perlu diulangi. Nilai eigen vector yang dimaksud adalah nilai eigen vector maximum yang diperoleh dengan menggunakan matlab maupun manual

Tabel 6 matriks perbandingan berpasangan aspek pelanggan

\begin{tabular}{lccccc}
\hline & CRE & CA & PC & PTD & SR \\
\hline CRE & 1.000 & 3.000 & 5.000 & 4.000 & 5.000 \\
\hline CA & 0.333 & 1.000 & 3.000 & 2.000 & 3.000 \\
\hline PC & 0.200 & 0.333 & 1.000 & 0.500 & 0.333 \\
\hline PTD & 0.250 & 0.500 & 3.000 & 1.000 & 0.200 \\
\hline SR & 0.200 & 5.000 & 3.000 & 3.000 & 1.000 \\
\hline & 1.983 & 9.833 & 15.000 & 10.500 & 9.533 \\
\hline
\end{tabular}

Tabel. 7 Matriks perbandingan hasil normalisasi aspek pelanggan

\begin{tabular}{lcccc}
\hline & CRE & CA & PC & PTD \\
\hline CRE & 0.504 & 0.305 & 0.333 & 0.381 \\
\hline CA & 0.168 & 0.102 & 0.200 & 0.190 \\
\hline PC & 0.101 & 0.034 & 0.067 & 0.048 \\
\hline PTD & 0.126 & 0.051 & 0.200 & 0.095 \\
\hline SR & 0.101 & 0.508 & 0.200 & 0.286 \\
\hline
\end{tabular}

Tabel 8 Lanjutan Matriks perbandingan hasil normalisasi aspek pelanggan

\begin{tabular}{cccc}
\hline SR & Jumlah & $\begin{array}{c}\text { Bobot } \\
\text { Prioritas }\end{array}$ & $\begin{array}{c}\text { Nilai } \\
\text { Eigen }\end{array}$ \\
\hline 0.524 & $\mathbf{2 . 0 4 8}$ & 0.410 & 5.000000 \\
\hline 0.315 & 0.975 & 0.195 & 5.000000 \\
\hline 0.035 & 0.284 & 0.057 & 5.000000 \\
\hline 0.021 & 0.493 & 0.099 & 5.000000 \\
\hline 0.105 & 1.200 & 0.240 & 5.000000 \\
\hline & & $\mathbf{1 . 0 0 0}$ & 25.000000 \\
\hline
\end{tabular}


Findawati, dkk., Pengembangan Aplikasi Web Pengukuran Kinerja UMKM menggunakan Metode..

Nilai eigen $\mathrm{CRE}=2,048 / 0,410=5$

Nilai eigen $\mathrm{CA}=0,975 / 0,195=5$

Nilai eigen $\mathrm{PC}=0,284 / 0,057=5$

Nilai eigen $\mathrm{PTD}=0,493 / 0,099=5$

Nilai eigen $S R=1,2 / 0,240=5$

\section{Hasil Consistency Index (CI)}

$\mathrm{CI}=\left(\square_{\max }-\mathrm{n}\right) / \mathrm{n}-1=(5-5 / 5-1=0 / 4=0$

Jadi, 0 merupakan hasil dari consistency index

Hasil Consistency Ratio (CR)

$\mathrm{CR}=($ Hasil CI / Nilai Indeks Random kolom

ke 3$)=0 / 1,12=0$

Jadi, 0 merupakan hasil dari consistency ratio

Karena $\mathrm{CR}=0<0,1$, maka matriks perbandingannya konsisten.

Selanjutnya Untuk pembobotan subkriteria pada aspek proses pembelajaran dan pertumbuhan juga menggunakan metode AHP dapat dilihat pada proses berikut:

1. Membentuk matriks perbandingan berpasangan yang menggambarkan kontribusi relatif atau pengaruh setiap elemen terhadap masing-masing tujuan atau kriteria yang setingkat diatasnya. (Tabel 9, 10, 11)

2. Menormalkan data yaitu dengan membagi nilai dari setiap elemen di dalam matriks yang berpasangan dengan nilai total dari setiap kolom

3. Menghitung nilai eigen vector dan menguji konsistensinya, jika tidak konsisten pengambil data (preferensi) perlu diulangi. Nilai eigen vector yang dimaksud adalah nilai eigen vector maximum yang diperoleh dengan menggunakan matlab maupun manual

Nilai eigen $\mathrm{ETO}=1,058 / 0,176=6$

Nilai eigen $\mathrm{SR}=0,691 / 0,115=6$

Nilai eigen abseenteisme $=0,894 / 0,149=6$

Nilai eigen TARD $=0,962 / 0,160=6$

Nilai eigen $\mathrm{PNE}=0,791 / 0,132=6$

Nilai eigen $\mathrm{ET}=1,603 / 0,267=6$

Tabel 9 Matriks perbandingan berpasangan aspek proses pembelajaran dan pertumbuhan

\begin{tabular}{lcccccc}
\hline & ETO & SR & ABSEN & TARD & PNE & ET \\
\hline ETO & 1.000 & 3.000 & 2.000 & 3.000 & 3.000 & 0.333 \\
\hline SR & 0.333 & 1.000 & 3.000 & 3.000 & 0.333 & 0.500 \\
\hline ABSEN & 0.500 & 0.333 & 1.000 & 3.000 & 2.000 & 2.000 \\
\hline TARD & 0.333 & 0.333 & 3.000 & 1.000 & 3.000 & 2.000 \\
\hline PNE & 0.333 & 5.000 & 0.500 & 3.000 & 1.000 & 0.333 \\
\hline ET & 3.000 & 5.000 & 3.000 & 1.000 & 3.000 & 1.000 \\
\hline & 5.500 & 14.667 & 12.500 & 14.000 & 12.333 & 6.167 \\
\hline
\end{tabular}

Tabel 10. Matriks perbandingan hasil normalisasi aspek aspek proses pembelajaran dan pertumbuhan

\begin{tabular}{cccccc}
\hline & ETO & SR & ABSEN & TARD & PNE \\
\hline ETO & 0.182 & 0.205 & 0.160 & 0.214 & 0.243 \\
\hline SR & 0.061 & 0.068 & 0.240 & 0.214 & 0.027 \\
\hline ABSEN & 0.091 & 0.023 & 0.080 & 0.214 & 0.162 \\
\hline TARD & 0.061 & 0.023 & 0.240 & 0.071 & 0.243 \\
\hline PNE & 0.061 & 0.341 & 0.040 & 0.214 & 0.081 \\
\hline ET & 0.545 & 0.341 & 0.240 & 0.071 & 0.243 \\
\hline
\end{tabular}

Tabel 11. Lanjutan Matriks perbandingan hasil normalisasi aspek aspek proses pembelajaran dan pertumbuhan

\begin{tabular}{cccc}
\hline ET & Jumlah & $\begin{array}{c}\text { Bobot } \\
\text { Prioritas }\end{array}$ & Nilai Eigen \\
\hline 0.054 & 1.058 & 0.176 & 6.000000 \\
\hline 0.081 & 0.691 & 0.115 & 6.000000 \\
\hline 0.324 & 0.894 & 0.149 & 6.000000 \\
\hline 0.324 & 0.962 & 0.160 & 6.000000 \\
\hline 0.054 & 0.791 & 0.132 & 6.000000 \\
\hline 0.162 & 1.603 & 0.267 & 6.000000 \\
\hline & & 1.000 & 36.000000 \\
\hline
\end{tabular}

Hasil Consistency Index (CI)

$\mathrm{CI}=\left(\square_{\max }-\mathrm{n}\right) / \mathrm{n}-1=6-6 / 6-1=0 / 5=0$

Jadi, 0 merupakan hasil dari consistency index

Hasil Consistency Ratio (CR)

$\mathrm{CR}=($ Hasil CI/Nilai Index Random kolom ke 3) $=0 / 1,24=0$

Jadi, 0 merupakan hasil dari consistency ratio. Karena $\mathrm{CR}=0<0,1$, maka matriks perbandingannya konsisten

$\underline{\text { b. Analisa pembobotan indikator pilihan pada }}$ subkriteria sebagai berikut

Untuk analisa pembobotan indikator pilihan pada subkriteria dapat dilihat pada tabel sebagai berikut

WPM proses pembelajaran \& pertumbuhan $\max =0,5^{0,176} * 0,333^{0,115} * 0,5^{0,149} * 0,333$ $0,16 * 0,5^{0,13} * 0,5^{0,267}=0,44701502$

Menghitung total pengukuran kinerja UMKM dengan nilai maksimal dengan AHP

AHP global dengan nilai maksimal $=\left(0,5^{*}\right.$ $0,597)+(0,5 * 0,055)+(0,5 * 0,229)+(0,5 * 0,119=$ 0,5

Perhitungan pengukuran kinerja UMKM dengan nilai minimal adalah:

1. Menghitung aspek keuangan

WPM Keuangan min $=0,167^{0,049} * 0,167^{0,23} *$ $0,167^{0,327} * 0,167^{0,167} * 0,167^{0,10} * 0,167^{0,12}$ $=0,167$ 
Jurnal Sistem Informasi, Volume 5, Nomor 1, Maret 2014, hlm. 15-27

2. Menghitung aspek pelanggan

WPM Pelanggan min $=0,167^{0,41} * 0,167^{0,195}$

$* 0,167^{0,057} * 0,167^{0,099} * 0,167^{0,24}=0,167$

3. Menghitung proses bisnis internal

WPM proses bisnis internal $\min =0,167^{0,17} *$ $0,167^{0,115} * 0,167^{0,149} * 0,167^{0,160} * 0,167$ $0,131 * 0,167^{0,267}=0,167$

4. Menghitung proses pembelajaran dan pertumbuhan

WPM proses pembelajaran \& pertumbuhan $\min$ $=0,167^{0,176} * 0,167^{0,115} * 0,167^{0,149} * 0,167$ $0,16 * 0,167^{0,13} * 0,167^{0,267}=0,167$

Menghitung total pengukuran kinerja UMKM dengan nilai maksimal dengan AHP

AHP global dengan nilai minimal $=(0,167 *$ $0,597)+(0,167 * 0,055)+(0,167 * 0,229)+(0,167 * 0$, $119)=0,167$

Sehingga didapat range pengukuran yaitu :

Range pengukuran yaitu $=(\max -\min ) / 5=0,5-$ $0,167 / 5=0,0666$
Tabel 12. Tabel range hasil pengukuran kinerja

\begin{tabular}{rrrrl}
\hline No & \multicolumn{2}{c}{ Range } & \multicolumn{1}{c}{$\begin{array}{c}\text { hasil } \\
\text { pengukuran } \\
\text { kinerja }\end{array}$} \\
\hline 1 & 0.167 & s/d & 0.2336 & Sangat Buruk \\
\hline 2 & 0.2336 & s/d & 0.3002 & Buruk \\
\hline 3 & 0.3002 & s/d & 0.3668 & Cukup \\
\hline 4 & 0.3668 & s/d & 0.4334 & Baik \\
\hline 5 & 0.4334 & s/d & 0.5 & Sangat Baik \\
\hline
\end{tabular}

\subsection{Perancangan use case diagram}

Adapun perancangan use case diagram untuk aplikasi pengukuran kinerja UMKM dapat dilihat pada gambar1.

Berdasarkan gambar 3. untuk fungsionalitas pada aplikasi ini adalah sebagai berikut:

1. Kelola kriteria: aplikasi ini mampu melakukan input indikator, update indikator, delete indikator dan proses perhitungan AHP

2. Kelola Sub Indikator: aplikasi ini mampu melakukan input sub indikator, update sub indikator dan delete sub indikator dan proses perhitungan AHP dan WPM

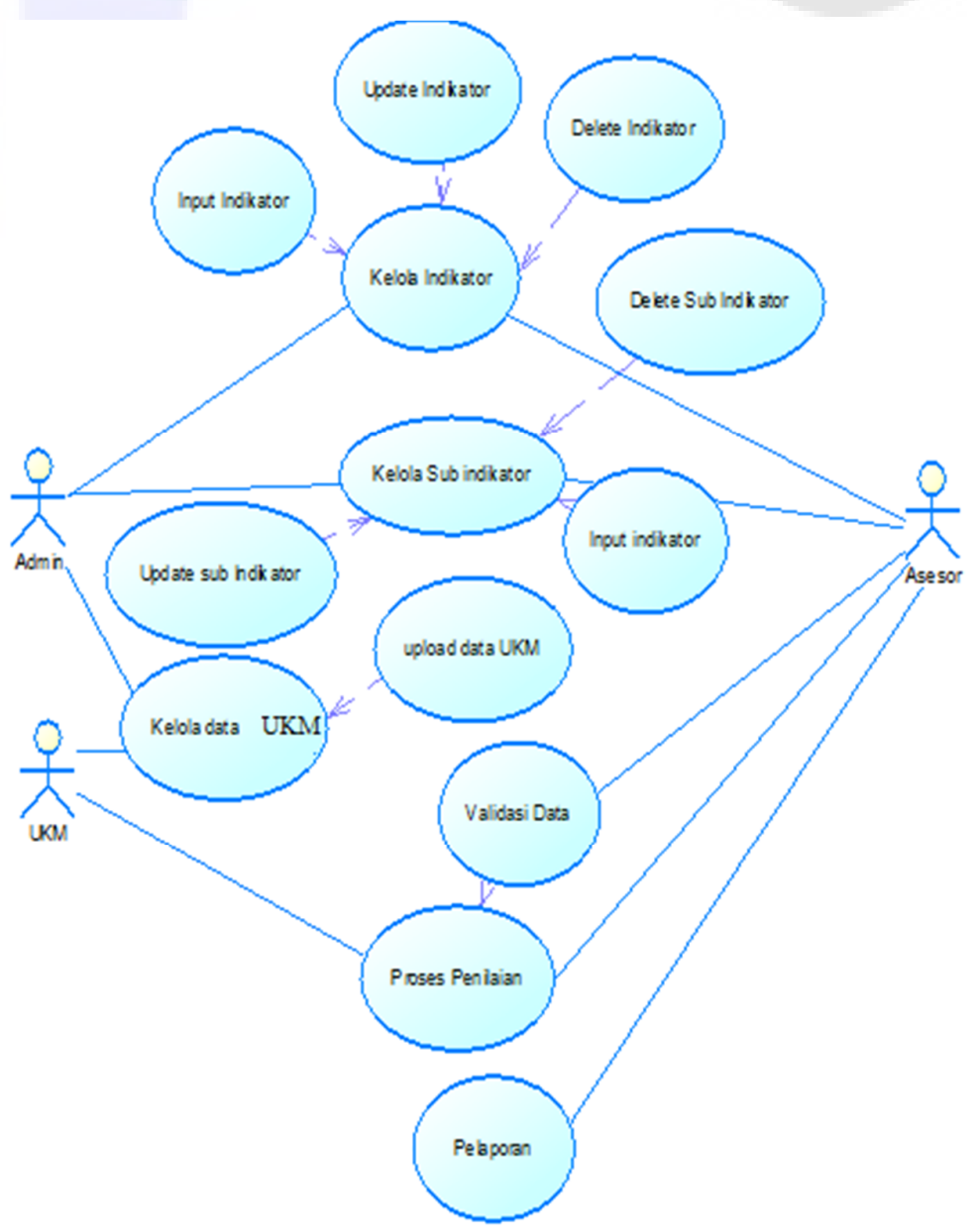

Gambar 3. Usecase Diagram aplikasi pengukuran kinerja UMKM berbasis web 
Findawati, dkk., Pengembangan Aplikasi Web Pengukuran Kinerja UMKM menggunakan Metode..

3. Kelola data UMKM: aplikasi ini memiliki fungsionalitas untuk input data UMKM yang terdiri atas data UMKM dan data aspek keuangan yaitu laba kotor perusahaan, modal awal perusahaan, jumlah aktiva, laba bersih setelah pajak, penjualan bersih, penjualan periode tahun ini, penjualan periode tahun sebelumnya.

4. Untuk aspek pelanggan melakukan input jumlah pelanggan lama, jumlah pelanggan baru, total pelanggan, keluhan jumlah transaksi, jumlah transaksi pertahun, jumlah pengiriman tapat waktu, total jumlah pengiriman, return penjualan. Untuk aspek proses bisnis internal terdiri atas input data rata-rata hari supplier mengirimkan barang, jumlah produk cacat, total produk dihasilkan, jumlah transaksi tahun sekarang, jumlah transaksi tahun sebelumnya. Sedangkan untuk aspek proses pembelajaran dan pertumbuhan jumlah pekerja yang keluar, total jumlah pekerja, jumlah saran karyawan, total hari pekerja absen, total hari pekerja bekerja. Jumlah hari karyawan terlambat, jumlah karyawan baru, jumlah karyawan yang mengikuti pelatihan.
5. Validasi data: yaitu proses untuk melakukan validasi data

6. Proses Perhitungan: yaitu proses untuk melakukan proses perhitungan aspek keuangan, pelanggan, proses bisnis internal dan pembelajaran dan pertumbuhan berdasarkan data UMKM

7. Pelaporan: proses untuk pelaporan kinerja UMKM

\subsection{Perancangan Class Diagram}

Adapun perancangan Class Diagram dapat dilihat pada gambar 4. Berdasarkan gambar 4 . Class diagram aplikasi ini terdiri atas nilai, penilaian, data UMKM, indikator, sub indikator, kelola indikator, kelola subindikator dan kelola data UMKM.

\subsection{Perancangan Sequence Diagram}

Berdasarkan gambar 5. Untuk sequence diagram penilaian pengukuran kinerja UMKM terdiri atas meliputi class form penilaian, penilaian, nilai, dan UMKM.

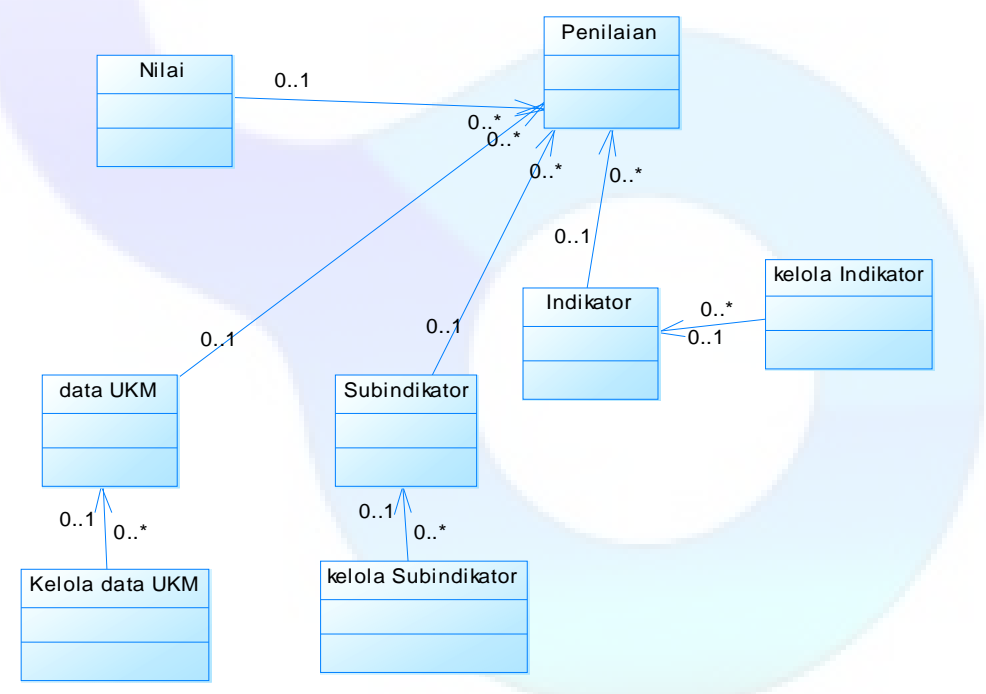

Gambar 4. Class Diagram aplikasi pengukuran kinerja UMKM berbasis web

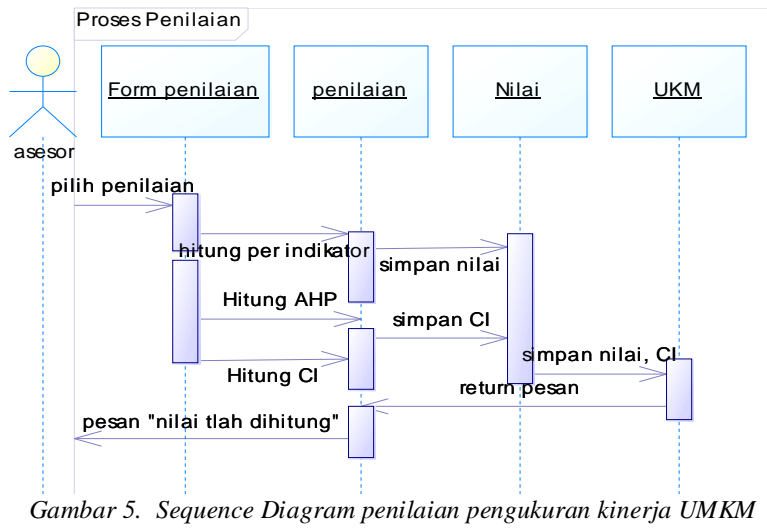


Jurnal Sistem Informasi, Volume 5, Nomor 1, Maret 2014, hlm. 15-27

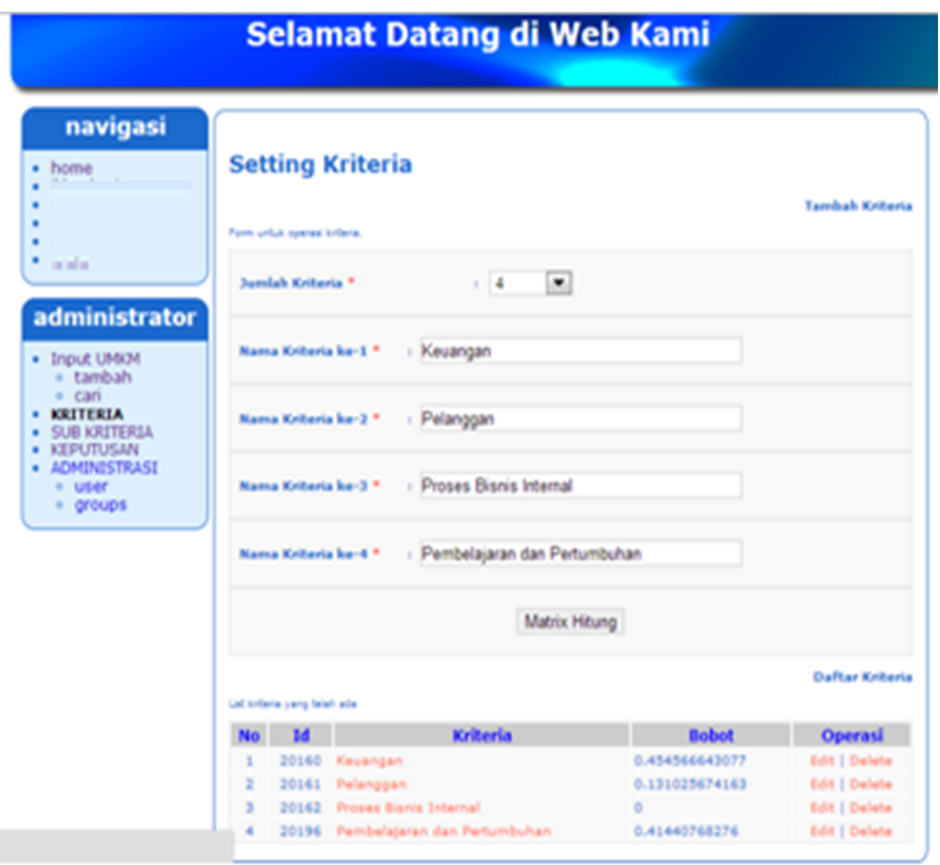

Gambar 6. Aplikasi web setting kriteria

\section{Selamat Datang di Web Kami}

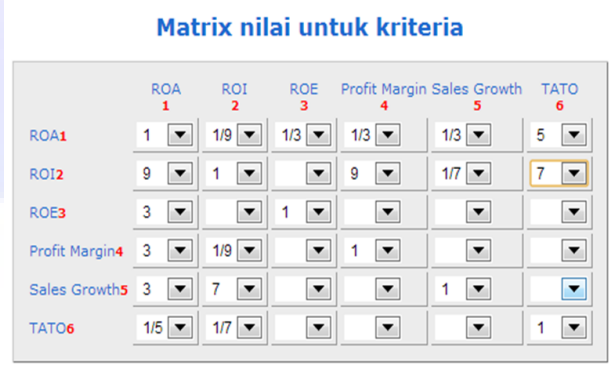

Gambar 7 . Perhitungan kriteria dengan pembobotan AHP

Tabel 13. Tabel pengukuran bobot keuangan

\begin{tabular}{lrrrrrrr}
\hline UKM & roa & roi & roe & p.mar & Sg & tato & Hasil \\
\hline ukm a & 0.5 & 0.5 & 0.333 & 0.5 & 0.5 & 0.333 & 0.416 \\
\hline ukm b & 0.333 & 0.333 & 0.5 & 0.5 & 0.333 & 0.5 & 0.427 \\
\hline ukm c & 0.333 & 0.333 & 0.333 & 0.333 & 0.333 & 0.333 & 0.333 \\
\hline ukm d & 0.333 & 0.333 & 0.333 & 0.333 & 0.333 & 0.333 & 0.333 \\
\hline ukm e & 0.5 & 0.333 & 0.5 & 0.333 & 0.5 & 0.333 & 0.404 \\
\hline
\end{tabular}

Tabel 14. Tabel hasil pengukuran bobot pembelajaran dan pertumbuhan

\begin{tabular}{lrrrrrr}
\hline UKM & roa & roi & roe & p.mar & Sg & Hasil \\
\hline ukm a & 0.333 & 0.333 & 0.333 & 0.333 & 0.333 & 0.33263403 \\
\hline ukm b & 0.5 & 0.5 & 0.5 & 0.5 & 0.333 & 0.453213449 \\
\hline ukm c & 0.5 & 0.5 & 0.5 & 0.333 & 0.333 & 0.435338161 \\
\hline ukm d & 0.5 & 0.5 & 0.5 & 0.333 & 0.333 & 0.435338161 \\
\hline ukm e & 0.333 & 0.333 & 0.333 & 0.333 & 0.333 & 0.33263403 \\
\hline
\end{tabular}


Findawati, dkk., Pengembangan Aplikasi Web Pengukuran Kinerja UMKM menggunakan Metode..

Tabel 15. Tabel hasil pengukuran bobot proses bisnis internal

\begin{tabular}{lrrrr}
\hline UKM & roa & roi & roe & Hasil \\
\hline $\mathrm{ukm} \mathrm{a}$ & 0.333 & 0.333 & 0.333 & 0.48290098 \\
\hline $\mathrm{ukm} \mathrm{b}$ & 0.5 & 0.333 & 0.5 & 0.58384238 \\
\hline $\mathrm{ukm} \mathrm{c}$ & 0.5 & 0.333 & 0.5 & 0.58384238 \\
\hline $\mathrm{ukm} \mathrm{d}$ & 0.333 & 0.5 & 0.5 & 0.5349862 \\
\hline $\mathrm{ukm} \mathrm{e}$ & 0.333 & 0.333 & 0.333 & 0.48290098 \\
\hline
\end{tabular}

Tabel 16. Tabel hasil pengukuran bobot pelanggan

\begin{tabular}{lrrrrrr}
\hline UKM & roa & roi & roe & p.mar & Sg & Hasil \\
\hline ukm a & 0.333 & 0.333 & 0.333 & 0.333 & 0.5 & 0.366 \\
\hline ukm b & 0.333 & 0.333 & 0.333 & 0.333 & 0.5 & 0.366 \\
\hline ukm c & 0.333 & 0.333 & 0.333 & 0.333 & 0.333 & 0.332 \\
\hline ukm d & 0.333 & 0.333 & 0.333 & 0.333 & 0.5 & 0.366 \\
\hline UKM e & 0.333 & 0.333 & 0.333 & 0.5 & 0.333 & 0.346 \\
\hline
\end{tabular}

Tabel 17. Tabel hasil pengukuran kinerja UMKM

\begin{tabular}{lcccccc}
\hline UKM & $\begin{array}{c}\text { Bobot } \\
\text { Keuangan }\end{array}$ & $\begin{array}{c}\text { Bobot } \\
\text { Pelanggan }\end{array}$ & $\begin{array}{c}\text { Bobot Proses } \\
\text { Bisnis }\end{array}$ & $\begin{array}{c}\text { Bobot P } \\
\text { dan P }\end{array}$ & Bobot & $\begin{array}{c}\text { Hasil } \\
\text { kinerja }\end{array}$ \\
\cline { 2 - 6 } ukm a & 0.597 & 0.055 & 0.229 & 0.119 & & baik \\
\hline ukm b & 0.416 & 0.3669 & 0.482 & 0.332 & 0.419 & $\begin{array}{c}\text { sangat } \\
\text { baik }\end{array}$ \\
\hline ukm c & 0.427 & 0.3669 & 0.583 & 0.453 & 0.463 & baik \\
\hline ukm d & 0.333 & 0.4353 & 0.583 & 0.332 & 0.396 & baik \\
\hline ukm e & 0.333 & 0.4353 & 0.534 & 0.366 & 0.388 & baik \\
\hline
\end{tabular}

\section{HASIL DAN PEMBAHASAN}

Hasil implementasi aplikasi pengukuran Kinerja pembelajaran dan pertumbuhan dapat dilihat pada gambar 6. Pada gambar 6 menunjukkan form untuk setting kriteria balanced scorecard. Pada gambar 7 adalah form input bobot kepentingan AHP. Hasil pengujian pengukuran kinerja UMKM berdasarkan data kuesioner UMKM yang disebarkan ke 50 UMKM Sidoarjo hasilnya dapat dilihat pada tabel sebagai berikut. Adapun data yang ditampilkan mengambil 5 sample data berdasarkan Tabel 17 tersebut terlihat bahwa perspektif keuangan mempunyai bobot terbesar terhadap kinerja UMKM yaitu 0.597 kemudian diikuti bobot proses bisnis internal (0.229), bobot pembelajaran dan pertumbuhan (0.119), dan bobot pelanggan (0.055). Rata-rata kinerja UMKM di sidoarjo adalah 0.4155 (Kategori Baik). Pada perspektif keuangan, rata-rata nilai tertinggi yaitu pada ROA (Return on Total Asset) sedangkan ratarata nilai terendah pada ROI (Return Of Investment), hal ini disebabkan karena penjualan bersih pada UMKM masih rendah. Oleh karena itu UMKM perlu meningkatkan hasil penjualan bersihnya.
Pada perspektif pembelajaran dan pertumbuhan, rata-rata nilai tertinggi yaitu pada ETO (Employee turn Over) sedangkan nilai terendah yaitu ET (Employee Training). Dari hal tersebut nilai ETO yang tinggi merugikan bagi UMKM karena proses merekrut karyawan baru diperlukan berbagai macam biaya, selain itu nilai ET yang rendah menunjukkan UMKM masih jarang memberikan pelatihan pada karyawan untuk mengembangkan UMKM sehingga menjadi UMKM yang berdaya saing.

Pada perspektif proses bisnis internal, rata-rata nilai tertinggi yaitu pada number of transaction sedangkan nilai terendah pada percentage of defective unit. Dari hal tersebut menunjukkan bahwa jumlah transaksi pada UMKM sangat baik dan jumlah cacat produk yang rendah. Pada perspektif pelanggan, rata-rata nilai tertinggi yaitu nilai OTD (On Time Delivery) dan yang terendah yaitu CA (Customer Acquisition). Dari hal tersebut menunjukkan bahwa pengiriman barang pada pelanggan sangat baik sedangkan kemampuan mencari pelanggan baru masih rendah. 


\section{KESIMPULAN}

Dari penelitian ini dapat diambil kesimpulan sebagai berikut

1. Rata-rata kinerja UMKM di sidoarjo adalah 0.4155 (Kategori Baik). Perspektif keuangan mempunyai kontribusi (bobot) paling besar terhadap kinerja UMKM yaitu 0.597 kemudian diikuti bobot proses bisnis internal (0.229), bobot pembelajaran dan pertumbuhan (0.119), dan bobot pelanggan (0.055).

2. Pada perspektif keuangan, rata - rata nilai tertinggi yaitu pada ROA (Return on Total Asset) sedangkan rata-rata nilai terendah pada ROI (Return Of Investment), hal ini disebabkan karena penjualan bersih pada UMKM masih rendah. Oleh karena itu UMKM perlu meningkatkan hasil penjualan bersihnya.

3. Rata-rata nilai terendah pada perspektif pembelajaran dan pertumbuhan yaitu Employee Training. Oleh karena itu UMKM masih perlu untuk meningkatkan kemampuan karyawannya dengan cara memberikan pelatihan manajemen maupun pelatihan yang mampu meningkatkan daya saing UMKM.

4. Rata-rata nilai tertinggi pada perspektif pelanggan yaitu nilai OTD (On Time Delivery) dan yang terendah yaitu CA (Customer Acquisition). Dari hal tersebut menunjukkan bahwa pengiriman barang pada pelanggan sangat baik sedangkan kemampuan mencari pelanggan baru masih rendah. Sehingga UMKM perlu untuk meningkatkan kemampuan mencari pelanggan atau melakukan pemasaran yang luas dengan cara melalui web, facebook maupun jaringan internet sehingga pelanggan yang didapatkan semakin banyak.

\section{DAFTAR RUJUKAN}

Alasadi, R. \& Abdelrahim, A. .2007. Critical Analysis And Modelling of Small Business Performance(Case Study: Syria). Journal of Asia Entrepreneurship and Sustainability, Volume III, Issue 2.

Apriyudi, Yudhi. 2008. "Evaluasi kinerja berdasarkan metode Balanced Scorecard pada segmen UKM, segmen korporasi, dan PT. BNI, Tbk. Agregat”. Skripsi. Fakultas Pertanian. Institut Pertanian Bogor.

Kaplan. Robert S, Norton. David P. 1996.The Balanced Scorecard : "Translating Strategy Into Action”. Hardvard Business School Press, Boston Massachusetts.

Marbun. B. N., 1993, Kekuatan dan Kelemahan Perusahaan Kecil, Jakarta, PT. PustakaBinaman Prescindo.

Pfeffer, J. \& G. Salancik .1978.. The external control of organizations: a resource dependence perspective. New York: Harper \& Row

Saaty, Thomas L. "Fundamentals of Decision Making and Priority Theory". Pittsburgh, Pennsylvania: RWS Publications. ISBN 09620317-6-3. 2001

Saaty, Thomas L. 2008 . "Decision making with the analytic Hierarchy Process" Int.J.Services Sciences, Vol. 1, No. 1, 2008. Inderscience Enterprise Ltd.

Safirin, MT. 2010. Kajian Kinerja Industri Kecil dengan metode Balanced Scorecard dan Analiytical Hierarchy Process. Jurnal Teknik Industri. Universitas Muhammadiyah Malang. Vol. 11, No.1, 2010.

Sinaga, Pariaman. 2004 "Balanced Scorecard sebagai pengukuran kinerja koperasi dan UKM, apa mungkin". Infokop nomor 25 hal.55, tahun XX

SK Dir BI No 31/24/KEP/ DIR Tgl 5 Mei 1998, Usaha Mikro, Bank Indonesia

Sriyana, Jaka. 2010. "Strategi Pengembangan Usaha Kecil dan Menengah (UKM): Studi kasus di Kabupaten Bantul. Simposium Nasional 2010. Fakultas Ekonomi. Universitas Islam Indonesia, Yogyakarta.

Undang-Undang Nomor 20 tahun 2008, Kementerian Koperasi dan UKM

Yuwono, S. Sukarno, E. Ichsan, M. 2002 ."Petunjuk Praktis Penyusunan Balanced Scorecard, Menuju Organisasi yang berfokus pada Strategi”. Gramedia 